\title{
Dinamika Kesehatan Mental Penduduk Arab Saudi selama Pandemi Covid-19
}

\author{
Received May 17, 2020 | Accepted June 27, 2020 \\ Fajar Ruddin \\ fajarruddin.psi@gmail.com \\ King Saud University Riyadh, Arab Saudi
}

\begin{abstract}
This study aims to describe the mental health conditions of the Saudi Arabian during the Covid-19 pandemic and to analyze the factors that influence it. Qualitative method through observation, interviews and collection of qualitative documents was used in this study. The analysis group was divided into three; medical staff, patients and their families, and the general community. The result showed that no serious mass mental problems were found in Saudi Arabia. This was influenced by several factors, including the availability of free psychological counseling services, internalized religious values and strategic policies adopted by the government.

Keywords: anxiety, Covid-19, mental health, panic buying, religiosity
\end{abstract}

\section{PENDAHULUAN}

Coronavirus disease 2019 (Covid-19) menjadi teror nyata umat manusia. Sejak kasus pertama terdeteksi di Wuhan bulan Desember tahun lalu, pandemi Covid-19 masih belum jelas kapan berakhirnya. Data dari Johns Hopkins University menyebutkan bahwa Covid-19 hingga kini telah menginfeksi hampir 3,5 juta manusia dengan 240 ribu lebih diantaranya meninggal dunia (Johns Hopkins University, 4/5/20).

Hal tersebut membuat sebagian besar orang menjadi cemas, bukan hanya karena takut terinfeksi virus, melainkan juga karena berbagai stressor lain yang dihadapi dalam waktu bersamaan. Terbatasnya interaksi sosial, gelombang pemutusan hubungan kerja (PHK), dan ketidakpastian akhir pandemi Covid-19 menjadi stressor yang tidak kalah mencemaskan dibanding virus itu sendiri.

Sebagaimana diketahui bersama, demi menekan penyebaran Covid-19 banyak negara memberlakukan kebijakan pembatasan sosial/fisik (social/physical distancing) atau bahkan lockdown. Kebijakan ini memaksa masyarakat untuk tetap di rumah sehingga mereka kehilangan interaksi tatap muka dan intervensi sosial tradisional. Hal ini juga menimbulkan stres (Zhang, dkk, 2020). Meskipun kini telah tersedia banyak media komunikasi, tapi interaksi tatap muka (face to face) tetap tidak tergantikan.

Di sisi lain, pemberlakuan kebijakan lockdown dan semisalnya memaksa pelaku usaha untuk merumahkan atau mem-PHK pegawainya karena terhentinya produksi. Organisasi Buruh Internasional (International Labour Organization - ILO) memprediksi bahwa 25 juta orang akan kehilangan pekerjaan sebagai dampak dari Covid-19 (ILO, 2020). Farre, Fasani, dan Mueller (2018) dalam penelitiannya terhadap dampak pemutusan hubungan kerja (PHK) pada resesi ekonomi di Spanyol mengungkapkan bahwa kehilangan pekerjaan membuat individu mengalami masalah mental seperti stres, putus asa dan merasa tidak berguna.

Selanjutnya, akhir pandemi Covid-19 yang tidak pasti juga turut berperan dalam memengaruhi kondisi psikologis massa. Sampai saat ini para ahli hanya bisa 
memperkirakan akhir Covid-19 dengan perkiraan yang berbeda-beda. Hal tersebut semakin menegaskan ketidakpastian pandemi ini. Dar, Iqbal \& Mustahaq (2017) dalam penelitiannya melaporkan bahwa ketidakpastian pengendalian penyakit dan tingkat risikonya adalah salah satu kondisi yang paling membuat stres bagi manusia.

Dalam tiap keadaan yang menekan, baik karena bencana, pandemi, ketakutan dan ketidakpastian, berbagai macam permasalahan psikologis seperti kecemasan, depresi dan stres memang kerap muncul (Dar, dkk, 2017; Xiang, dkk, 2020). Permasalahan psikologis tersebut dapat menimpa siapa saja, baik petugas medis, korban yang terinfeksi, keluarga korban, bahkan masyarakat secara umum (Kang, dkk, 2020).

Keadaan tersebut dapat diperparah dengan pemberitaan yang kerap muncul baik di media elektronik maupun daring. Berita palsu (hoaks) yang sering muncul di media sosial dapat menimbulkan kecemasan, kebencian dan bahkan rasisme (Kadam \& Atre, 2020). Tidak hanya berita palsu, berita yang jelas dan akurat pun berpotensi menimbulkan kecemasan jika salah dipersepsi oleh publik (Jones, Waters, Holland, Bevins, \& Iverson, 2010).

Kecemasan ini akan memunculkan egoisme seperti panic buying, perilaku kapitalis, xenofobia, dan kecenderungan untuk mempercayai setiap berita di sosial media (Nicomedes \& Avila, 2020). Perilaku panic buying selama pandemi Covid-19 ditemukan di berbagai belahan dunia, mulai dari benua Eropa, Amerika, Australia, bahkan Asia. Hal ini akan mendatangkan dampak yang lebih buruk seperti kekacauan dan terganggunya stok pangan dan alat kesehatan.

Jika berbagai permasalahan mental tersebut tidak ditangani, maka dampak terburuknya adalah individu dapat melakukan bunuh diri. Sejauh ini telah terjadi tujuh kasus bunuh diri sebagai dampak pandemi Covid-19 di berbagai belahan dunia. Penyebabnya adalah karena kecemasan, depresi, putus asa, ketakutan hingga trauma (Thakur \& Jain, 2020). WHO dalam dokumen Mental Health Action Plan 2013-2020 menekankan bahwa faktor-faktor penentu kesehatan dan gangguan mental tidak sebatas pada kompetensi individu untuk mengelola pikiran, emosi, perilaku dan interaksi dengan orang lain. Lebih dari itu, ada juga peran sosial, budaya, ekonomi, politik dan lingkungan, termasuk juga kebijakan nasional, perlindungan sosial, standar hidup, kondisi kerja, dan dukungan sosial masyarakat.Oleh karena itu, upaya terbaik meningkatkan kesehatan mental masyarakat tidak boleh hanya berfokus pada upaya kuratif saja (berfokus pada klien), melainkan melalui upaya integratif dan komprehensif dengan meningkatkan kegiatan promotif, preventif, kuratif dan rehabilitatif.

Dalam Undang-undang Nomor 18 Tahun 2014 tentang Kesehatan Jiwa disebutkan bahwa upaya promotif ditujukan untuk menghilangkan stigma, diskriminasi, dan pelanggaran hak asasi yang sering menyasar penderita gangguan mental. Selain itu, promosi kesehatan mental juga ditujukan untuk meningkatkan pemahaman dan peran serta masyarakat terhadap kesehatan mental.

Kemudian upaya preventif diartikan sebagai suatu kegiatan untuk mencegah terjadinya gangguan mental dengan melibatkan peran serta keluarga, lembaga dan masyarakat. Selain mencegah terjadinya gangguan mental, upaya preventif juga berperan untuk mencegah timbulnya dampak yang lebih besar, seperti masalah psikososial, sedangkan upaya kuratif merupakan kegiatan pemberian pelayanan kesehatan terhadap penderita gangguan mental yang mencakup proses diagnosis dan penatalaksanaan yang tepat sehingga mereka dapat berfungsi kembali secara wajar di lingkungan keluarga, lembaga, dan masyarakat. Upaya ini membutuhkan keahlian dari tenaga medis yang kompeten di bidangnya, seperti psikolog dan psikiater. 

Adapun upaya rehabilitatif diartikan sebagai suatu kegiatan dan/atau serangkaian kegiatan pelayanan kesehatan mental yang diantaranya bertujuan untuk memulihkan fungsi sosial, fungsi okupasional, dan persiapan penderita gangguan mental agar bisa hidup mandiri di tengah masyarakat. Upaya tersebut dapat ditempuh dengan memberikan bimbingan mental spiritual, konseling psikososial, bimbingan fisik dan bantuan sosial.

Di tengah kondisi dunia yang dilanda Covid-19 seperti sekarang ini, maka upayaupaya tersebut tidak boleh terputus atau berjalan sendiri-sendiri, tetapi harus tetap terintegrasi mulai dari upaya promotif hingga rehabilitatif. Sehingga beban berat akibat kesehatan jasmani yang terancam Covid-19 tidak bertambah berat karena gangguan mental.

Arab Saudi melaporkan kasus pertama Covid-19 pada tanggal 3 Maret 2020. Sampai saat ini, berdasarkan data yang dikeluarkan oleh Kementerian Kesehatan Kerajaan Arab Saudi, total kasus yang terkonfirmasi positif corona mencapai 25.459 dengan 176 diantaranya meninggal (Ministry of Health, 3/5/20). Demi mencegah permasalahan mental/psikologis akibat Covid-19 seperti yang telah dijelaskan di atas, maka perlu dilakukan upaya integratif dan komprehensif dari berbagai stakeholders.

Penelitian ini bertujuan memaparkan dinamika kesehatan mental penduduk Arab Saudi selama pandemi Covid-19 dengan fokus penelitan pada tiga kelompok, yaitu petugas medis, pasien dan keluarganya serta masyarakat secara umum. Penelitian ini juga mencoba menganalisis kebijakan-kebijakan apa saja yang diambil oleh stakeholders demi menekan dampak psikologis tersebut.

\section{METODE}

Penelitian ini menggunakan metode kualitatif, yaitu prosedur penelitian yang menghasilkan data deskriptif berupa ucapan, tulisan, atau perilaku yang dapat diamati dari subjek penelitian itu sendiri. Metode kualitatif biasanya digunakan untuk menjawab pertanyaan mengapa dan bagaimana suatu fenomena dapat terjadi. Narasumber dalam penelitian ini terdiri dari enam orang, yaitu tiga orang dari petugas medis (dua dokter dan satu perawat) dan tiga orang lainnya dari masyarakat umum.

Prosedur pengumpulan data dilakukan dengan empat strategi, seperti yang dijelaskan oleh Creswell (2009), yaitu melalui observasi, wawancara, pengumpulan dokumen kualitatif (koran, makalah, berita) dan materi audio dan visual (siaran resmi dari akun media sosial). Proses pengumpulan data dilakukan sejak awal mula munculnya kasus Covid-19 di Arab Saudi, yaitu tanggal 3 Maret sampai 3 Mei 2020. Data yang didapat kemudian ditranskripsi dan dikategorisasikan sesuai dengan topik penelitian. Selanjutnya, data disajikan dalam bentuk teks (narasi).

\section{HASIL}

\section{Kesehatan Mental Penduduk Arab Saudi selama Pandemi Covid-19}

World Health Organization (2018) mendefinisikan kesehatan mental sebagai kondisi sejahtera yang ditandai dengan empat indikator yaitu, individu menyadari kemampuannya sendiri, dapat mengatasi tekanan/stres kehidupan sehari-hari, bekerja dengan produktif dan mampu memberi kontribusi bagi komunitasnya. Artinya, mental yang sehat bukan berarti terbebas dari stres, tapi bagaimana individu dapat mengelola stres tersebut sehingga individu tetap produktif dan bermanfaat bagi masyarakat.

Dalam penelitian ini, kesehatan mental penduduk Arab Saudi pada masa pandemi Covid-19 dibahas dalam tiga kelompok utama, yaitu petugas medis, pasien dan keluarganya serta masyarakat secara umum. 

Temuan penelitian menunjukkan bahwa petugas medis yang menangani Covid-19 menjadi kelompok yang paling mengalami tekanan mental selama masa pandemi ini. Beban kerja yang meningkat tiga kali lipat serta adanya kekhawatiran karena takut tertular meningkatkan stres dan paranoid petugas medis. Hal ini disampaikan oleh RD sebagai berikut.

"Beban kerja meningkat tiga kali lipat dan ada kekhawatiran yang sebenarnya tidak diperlukan sehingga meningkatkan stres dan paranoia”

Selain itu, ada kekhawatiran yang dirasakan para petugas medis bahwa mereka dapat membawa virus tersebut ke rumah dan menularkan keluarga mereka sehingga tidak sedikit dari mereka yang mengisolasi diri di hotel. Tingginya beban kerja dengan kondisi yang berbahaya ditambah berkurangnya kualitas dukungan sosial (social support) dari keluarga membuat stressor yang harus dihadapi petugas medis jadi lebih berat sebagaimana yang disampaikan oleh OF berikut ini.

"Di satu sisi, ini adalah pekerjaan kami, tugas agama dan profesional kami, tapi di sisi lain, hati kami ditakuti perasaan bahwa kami akan menularkan keluarga kami",

Kelompok selanjutnya adalah pasien dan keluarganya. Salah satu stressor yang paling menekan yang dihadapi pasien dan keluarganya, selain Covid-19 itu sendiri, adalah stigma masyarakat. Bahkan di Indonesia pasien positif Covid-19 pertama dipasangi garis polisi di sekeliling rumahnya (Kumparan 2/3/20). Padahal hal tersebut dapat meresahkan masyarakat dan menjadikan pasien seolah-olah melakukan suatu kejahatan.

Adapun pasien positif Covid-19 di Arab Saudi tidak pernah dibuka identitasnya. Sejak kasus pertama muncul pada tanggal 3 Maret sampai 3 Mei, yang menjadi akhir penelitian ini, pemerintah bersama media hanya memberitakan data statistik tentang jumlah pasien positif, jumlah kesembuhan dan kematian. Tidak terdapat berita yang mengeksploitasi pasien Covid-19, apalagi terkait informasi pribadi mereka.

Kelompok terakhir adalah masyarakat umum. Berdasarkan observasi yang peneliti lakukan di tiga supermarket berbeda di Riyadh selama masa pandemi Covid-19, tidak ditemukan adanya panic buying masyarakat sebagai respon kecemasan akibat Covid-19. Mereka berbelanja sesuai dengan kebutuhannya, tidak ada pemborongan barang besarbesaran sehingga stok barang di supermarket terjaga.

Selain tidak ditemukan perilaku panic buying, masyarakat juga mematuhi peraturan lockdown yang diterapkan secara bertahap di Arab Saudi. Tidak ada protes atau penolakan dari masyarakat atas peraturan ini. Walaupun berada pada situasi lockdown, tetapi itu tidak menghalangi aktivitas harian mereka seperti sekolah, kuliah, dan bekerja. Aktivitasaktivitas tersebut tetap dilakukan dari rumah dengan menggunakan internet. Jika mengacu pada definisi kesehatan mental WHO, maka berdasarkan pengamatan yang telah dilakukan dapat disimpulkan bahwa tidak ada indikasi permasalahan mental/psikologis yang serius yang dialami penduduk Arab Saudi akibat pandemi Covid-19 ini.

Kebijakan-Kebijakan Stakeholders dalam Menekan Dampak Psikologis

Kondisi mental/psikologis yang relatif normal pada penduduk Arab Saudi selama masa pandemi Covid-19 bukanlah suatu hal yang terjadi begitu saja. Tentu ada faktorfaktor yang berperan di dalamnya. Beberapa faktor yang mempengaruhi kondisi tersebut diantaranya adalah: pertama, karena tersedianya layanan konsultasi psikologi. 

Merespon pentingnya kesehatan mental selama pandemi Covid-19, Kementerian Kesehatan Arab Saudi membuka layanan konsultasi psikologi gratis bagi masyarakat pada tanggal 29 Maret 2020. Tujuan dari program ini, selain memberikan konseling dan dukungan psikososial, juga untuk mengedukasi masyarakat tentang pentingnya kesadaran terkait virus corona.

Layanan ini ditujukan kepada tiga kelompok utama, yaitu petugas medis, pasien dan keluarganya serta masyarakat umum yang merasakan kepanikan dan kecemasan terhadap virus corona. Konsultasi psikologi bisa dilakukan melalui tiga cara, yaitu sambungan telepon, teks WhatsApp, atau mengirimkan pesan langsung (direct message) ke akun media sosial mereka seperti Snapchat, Twitter, dan Telegram.

Selain tindakan kuratif, Kementerian Kesehatan melalui Divisi Kesehatan Mental juga melakukan tindakan promotif terkait kesehatan mental melalui akun sosial media mereka. Dalam akun tersebut, mereka mengampanyekan bagaimana menjaga kondisi psikologis agar tidak cemas dan stres selama pandemi. Keaktifan mereka dalam membahas isu-isu kesehatan mental selama masa pandemi, dari program promotif hingga kuratif, berdampak baik bagi kesehatan mental masyarakat.

Faktor kedua adalah peran ulama. Arab Saudi dikenal sebagai bangsa yang religius. Dalam The Basic Law of Governance (UUD versi Arab Saudi), Islam adalah satu-satunya agama yang diakui di negara tersebut. Konstitusi Arab Saudi berkiblat pada Al-Qur'an (Kitab Allah) dan Sunnah Rasulullah shallallahu 'alaihi wasallam (Saudi Arabia's Constitution of 1992). Dalam kalender mereka, hanya ada dua hari libur nasional, yaitu libur Idul Fitri dan Idul Adha. Religiusitas ini semakin diperkuat dengan adanya dua tempat suci di negara tersebut, yaitu Mekkah Al-Mukarromah dan Madinah AlMunawwaroh.

Sebagai bangsa yang religius, peran ulama sangat besar pengaruhnya dalam kehidupan masyarakat. Di Arab Saudi, ulama memiliki naungan sendiri di bawah Majelis Dewan Ulama Senior (The Council of Senior Scholars). Ini adalah badan keagamaan tertinggi Kerajaan Arab Saudi yang bertugas menasihati raja dalam urusan yang ada kaitannya dengan agama di negara tersebut. Dalam kaitannya dengan dengan pandemi Covid-19, ulama seringkali memberikan nasihat seperti yang dituturkan oleh subjek SM berikut.

\footnotetext{
"Ulama memberikan pemahaman kepada kami tentang maqashid ad-din al-khomsah [lima tujuan agama] yang diantaranya adalah hifdz an-nafs [menjaga jiwa]. Hal itu menurut saya menguatkan kepatuhan masyarakat terhadap imbauan pemerintah. Di samping juga menasihati kami agar selalu bersabar dalam menghadapi ujian"
}

Faktor ketiga yang berperan dalam menekan dampak psikologis pada warga Arab Saudi adalah aturan dan kebijakan pemerintah yang jelas dan memihak. Ketika negara lain dilanda panic buying, pemerintah melalui Kementerian Perdagangan menjamin stok kebutuhan pokok terjaga sehingga tidak perlu melakukan panic buying (Ministry of Commerce, 2020). Tidak hanya itu, pemerintah juga menjamin stabilitas harga dan kecurangan dari para pelaku monopoli, dan jaminan tersebut bukan sekadar janji kosong, tapi benar-benar ditepati. Hal ini menimbulkan ketenangan bagi warga seperti yang disampaikan oleh subjek BD berikut ini.

"Kementerian Perdagangan memberikan rasa aman bagi kami terkait kebutuhan sehari-hari sehingga kami tidak cemas akan kehabisan makanan” 

Kebijakan pemerintah didukung oleh sektor swasta dimana para pelaku usaha ritel menggaransikan ketersediaan kebutuhan pokok masyarakat dan mereka juga menyediakan jasa layanan antar untuk mendukung gerakan pembatasan sosial sehingga masyarakat dapat berbelanja dari rumah tanpa harus mengunjungi supermarket. Kalaupun masyarakat harus pergi ke supermarket, maka di sana mereka akan mendapati protokol pencegahan Covid-19, seperti diminta memakai sarung tangan dan hand sanitizer yang telah mereka sediakan secara gratis.

Pemerintah juga mengirimkan pesan sms ke nomor-nomor warga setiap hari. Pesan tersebut berisi imbauan, nasihat, arahan dan petunjuk jika mengalami gejala-gejala seperti batuk dan kesulitan bernafas, disertai dengan nomor yang bisa dihubungi jika merasakan gejala tersebut.

Selain itu, pemerintah juga menerjemahkan pesan-pesan tersebut ke dalam beberapa bahasa mengingat Arab Saudi adalah salah satu negara dengan jumlah imigran yang sangat besar. Laporan International Migration 2019 dari United Nations menyebutkan ada 13 juta imigran yang tinggal di Arab Saudi (Department Economic and Social Affairs UN, 2019). Artinya, kurang lebih sepertiga dari total penduduk di Arab Saudi adalah imigran. Oleh karena itu, merangkul mereka untuk sama-sama melawan pandemi ini menjadi sangat penting. Di antara pesan-pesan tersebut contohnya sebagai berikut.

\footnotetext{
"Dengan mematuhi semua tindakan pencegahan, kita akan melalui masa sulit ini bersamasama. \#KitaSemuaBertanggungJawab”
}

Di samping itu, untuk menekan angka PHK selama masa pandemi, pemerintah juga membayar kompensasi sebesar $60 \%$ dari total gaji para pegawai Saudi yang bekerja di sektor swasta selama tiga bulan ke depan dengan syarat dan ketentuan yang diatur (Saudi Press Agency, 3/4/20).

\section{DISKUSI}

\section{Kesehatan Mental Penduduk Arab Saudi selama Pandemi Covid-19}

Petugas medis yang menjadi narasumber dalam penelitian ini merasakan kecemasan dan stres ketika bertugas selama pandemi Covid-19. Beban kerja yang meningkat, potensi terinfeksi Covid-19, dan kekhawatiran akan menularkan virus kepada keluarga yang membuat mereka harus menjaga jarak, baik fisik maupun sosial, menjadi stressor bagi subjek.

Hal ini bersesuaian dengan laporan Kang, dkk (2020) yang meneliti tentang kesehatan mental petugas medis di Wuhan selama masa pandemi Covid-19. Kang, dkk mendapati bahwa petugas medis di Wuhan menghadapi tekanan besar, termasuk resiko tinggi terinfeksi Covid-19. Mereka juga memiliki beban kerja yang tinggi, merasakan frustrasi, diskriminasi, isolasi, dan kurangnya kontak dengan keluarga. Kondisi tersebut menyebabkan masalah kesehatan mental seperti stres, kecemasan, gejala depresi, insomnia, penolakan (denial), kemarahan, dan ketakutan.

Menariknya, berbagai stressor yang dihadapi para petugas medis di Arab Saudi tidak menghentikan mereka untuk berkontribusi mengatasi pandemi Covid-19. Sebaliknya, di balik stressor yang dihadapi petugas medis, mereka menemukan kedamaian batin dan "penerimaan" dengan melihat hal-hal positif yang ada. Salah satu dokter bahkan mengatakan ini adalah berkah yang tersembunyi. 

Lebih dari itu, petugas medis menganggap bahwa pekerjaan mereka selama pandemi ini adalah pekerjaan patriotik yang tidak hanya mengandung nilai-nilai kemanusiaan, tetapi juga sebagai bentuk jihad di jalan Allah. Hal itu memunculkan penerimaan (acceptance) dalam diri petugas medis. Hasil penelitian Livheim, dkk (2015) menunjukkan bahwa penerimaan berperan penting dalam mengatasi depresi, kecemasan dan stres.

Selanjutnya, dirahasiakannya data pasien Covid-19 membantu pasien dan keluarganya untuk terhindar dari stigma masyarakat. Hal ini sangat penting karena selain berdampak pada kondisi mental individu, stigma juga dapat mencegah individu untuk mencari pertolongan sebagaimana yang sering terjadi pada penderita gangguan mental (Corrigan \& Bink, 2016). Hal itu dapat berdampak semakin buruk bagi pasien, keluarga dan masyarakat di sekitarnya.

Di berbagai belahan dunia, pasien positif Covid-19 mendapatkan dua kemalangan, selain penyakit itu sendiri, mereka juga rentan mendapat diskriminasi (Lin, 2020). Stigma yang diterima para pasien Covid-19 pada akhirnya memiliki konsekuensi negatif sebagaimana yang telah terjadi pada kasus SARS (Person, dkk, 2004) dan Ebola (Cheung, 2015).

Pada kelompok terakhir, yaitu masyarakat umum, masalah mental yang paling mudah ditemui pada masyarakat yang menghadapi peristiwa traumatis, seperti halnya pandemi Covid-19, adalah respon stres yang meningkat (Garfin, Thompson, \& Holman, 2018). Respon stres ini meningkatkan perilaku mencari bantuan (help-seeking behaviors) yang tidak proporsional seperti panic buying. Dampaknya terjadi kekurangan stok kebutuhan pokok dan medis dan melonjaknya harga kebutuhan-kebutuhan tersebut.

Akan tetapi pada penelitian ini tidak ditemukan adanya panic buying di tengah masyarakat. Selain itu, masyarakat juga menjalankan aktivitasnya sebagaimana mestinya, hanya saja aktivitas-aktivitas tersebut dilakukan di rumah. Hal ini menandakan bahwa masyarakat memiliki kesehatan mental yang baik, sesuai dengan definisi kesehatan mental dari WHO (2018) yang menerjemahkan kesehatan mental sebagai kondisi sejahtera yang meliputi empat indikator yaitu, individu menyadari kemampuannya sendiri, dapat mengatasi tekanan/stres kehidupan sehari-hari, bekerja dengan produktif dan mampu memberi kontribusi bagi komunitasnya.

Dengan kata lain, mental yang sehat bukan berarti terbebas dari stres, tapi bagaimana individu dapat mengelola stres tersebut sehingga individu tetap produktif dan bermanfaat bagi masyarakat. Hal ini ditegaskan oleh Victor Frankl dalam bukunya, Man's Search for Meaning (1985), yang mengatakan bahwa reaksi abnormal pada situasi abnormal adalah perilaku yang normal. Frankl ingin menegaskan bahwa kecemasan, stres dari kondisi krisis yang dihadapi individu adalah sebuah kewajaran. Hal itu Frankl sintesiskan berdasarkan pengalamannya menjalani dan mengobservasi kamp konsentrasi Perang Dunia II yang penuh tekanan baik secara fisik maupun mental.

\section{Kebijakan-Kebijakan Stakeholders dalam Menekan Dampak Psikologis}

Dalam menanggapi krisis psikologis yang terjadi selama pandemi Covid-19 di China, Zhang, dkk (2020) merekomendasikan agar berbagai pihak turut mengambil peran, mulai dari psikolog, psikiater, dokter hingga pekerja sosial. Mereka akan dihubungkan dengan pasien dan keluarganya serta petugas medis yang merasakan stres dan kecemasan melalui media internet.

Arab Saudi melalui Kementerian Kesehatan membuka layanan konsultasi psikologi gratis yang ditujukan bagi tiga kelompok utama, yaitu petugas medis, pasien dan 

keluarganya serta masyarakat umum yang merasakan kepanikan dan kecemasan akibat Covid-19.

Metode layanan seperti ini banyak dipakai di seluruh dunia dan kini dikenal dengan nama telemental health (Zhou, dkk, 2020). Layanan konsultasi tidak bisa diberikan secara langsung (face to face) mengingat adanya aturan lockdown yang diterapkan di Arab Saudi.

Kemajuan teknologi memudahkan para psikolog dan psikiater untuk memberikan layanan konseling. Kini masyarakat mudah mengakses layanan tersebut secara daring dengan efektivitas yang tidak kalah baiknya dengan metode tatap muka (Zhou, dkk, 2020). Hal ini sangat berbeda ketika masa pandemi SARS tahun 2003 lalu. Terbatasnya layanan konsultasi psikologi pada masa itu membuat permasalahan kesehatan mental menjadi bencana kedua setelah virus itu sendiri. Beberapa studi terdahulu melaporkan bahwa 10\%-35\% dari penyintas SARS memiliki kecemasan, depresi, atau keduanya sebulan setelah keluar dari rumah sakit (Au, dkk, 2004; Wu, dkk, 2005).

Permasalahan kesehatan mental tersebut tidak hanya terjadi sesaat setelah wabah berakhir saja, tapi berlangsung bertahun-tahun. Wu, dkk (2009) menemukan bahwa 10\% dari responden telah mengalami gejala stres pasca-trauma (posttraumatic stress) tingkat tinggi sejak wabah SARS tiga tahun sebelumnya. Responden yang dikarantina, atau bekerja di lokasi berisiko tinggi seperti bangsal SARS, atau yang memiliki kerabat dekat yang terjangkit SARS, memiliki tingkat gejala stres pasca-trauma 2 hingga 3 kali tinggi daripada mereka yang tidak memiliki paparan ini. Oleh karena itu, pelayanan konseling menjadi sangat penting agar tidak ada bencana kedua setelah wabah berakhir.

Selain menyediakan layanan konsultasi psikologi gratis, Arab Saudi juga terbantu oleh religiusitas warganya dalam menekan dampak psikologis akibat pandemi Covid-19. Penelitian tentang religiusitas dalam ranah ilmu psikologi telah banyak dilakukan. Berbagai penelitian tersebut menyimpulkan bahwa ada hubungan positif antara religiusitas dan kesehatan mental atau penyesuaian psikoloigs (psychological adjustment) (Hackney \& Sanders, 2003). Penghambaan dan ketaatan yang sejati kepada Tuhan memberikan satu kekuatan besar bagi manusia serta menjadi sumber kekuatan emosional dan moral spiritual yang konstan, yang membantu dalam melawan gangguan mental (Pajevic, Sinanovic, \& Hasanovic, 2005).

Di samping itu, para ulama juga secara aktif memberikan nasihat kepada masyarakat agar senantiasa bersabar dalam menghadapi ujian corona dan mengajak masyarakat untuk berdoa kepada Allah agar wabah penyakit ini segera diangkat (General Presidency for Scholarly Research and Fatwa, 2020). Syeikh Sa'ad bin Nashir Al-Syitsri yang menjadi anggota Dewan Ulama Senior misalnya mengingatkan masyarakat dengan hadits Rasulullah shallallahu 'alaihi wasallam yang berbunyi:

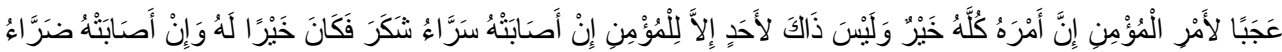

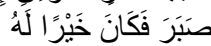

Abu-Ras, Gheith, \& Cournos (2008) menyebutkan bahwa ulama atau imam bagi seorang muslim tidak hanya dicari untuk keperluan bimbingan agama, tapi juga konseling. Oleh karena itu, Ali (2016) mendorong agar kalangan akademisi, klinisi dan 

agamawan untuk berkolaborasi mengingat pentingnya peran para ulama atau imam bagi kesehatan mental anggota masyarakat.

Selain mengondisikan masyarakat, ulama juga membesarkan hati keluarga korban corona yang meninggal dengan menyebut bahwa mayit mendapat pahala syahid. Begitu pula dengan para petugas medis, ulama menyebut mereka sedang berjihad di jalan Allah. Nasihat-nasihat ini membawa masyarakat pada kondisi menerima (acceptance) atas ujian yang sedang menimpa. Dengan penerimaan (acceptance), resiliensi individu atas kejadian traumatis menjadi lebih tinggi (Thompson, Arnkoff, \& Glass, 2011).

Selanjutnya, aturan dan kebijakan pemerintah Arab Saudi dalam menyikapi pandemi corona juga berperan besar pada kesehatan mental masyarakat. Untuk menghindari kecemasan akan terjadinya kelangkaan makanan, pemerintah melalui Kementerian Perdagangan mengumumkan keterjaminan stok pangan. Hal ini sangat penting karena kecemasan yang ditekan akan menghindarkan manusia dari perilaku egoisme seperti panic buying (Nicomedes \& Avila, 2020).

Selain itu, demi menekan angka PHK selama masa pandemi, pemerintah juga membayar kompensasi sebesar $60 \%$ dari total gaji para pegawai Saudi yang bekerja di sektor swasta. Dari sudut pandang kesehatan mental, kebijakan ini sangat membantu mencegah timbulnya permasalahan mental mengingat hasil penelitian menunjukkan bahwa PHK menimbulkan stres, putus asa, dan merasa tidak berguna (Farre, dkk, 2018).

Kebijakan pemerintah yang juga sangat berperan bagi kesehatan mental masyarakat adalah pemberantasan berita palsu (hoaks). Hukum di Arab Saudi sangat tegas dan keras dalam menindak pelaku hoaks dimana para pelaku akan dikenai denda sebesar SAR 3 juta (setara Rp 12 miliar) dan kurungan penjara 5 tahun. Hal ini sangat penting mengingat hoaks sangat mudah menimbulkan kepanikan masyarakat, terlebih di era internet seperti sekarang ini. Meningkatnya kejadian bencana, termasuk juga pandemi, biasanya disertai pula dengan peningkatan berita hoaks atau berita yang telah terfabrikasi sehingga menimbulkan kesalahpahaman (Azim, Dey, Aich, \& Roy, 2020).

\section{KESIMPULAN}

Pandemi Covid-19 dapat berdampak tidak hanya pada kesehatan fisik saja, tapi juga kesehatan mental. Oleh karena itu, selain menjaga kesehatan fisik, manusia juga perlu menjaga kesehatan mentalnya. Kelompok yang rentan mengalami permasalahan mental selama pandemi ini diantaranya adalah petugas medis, pasien dan keluarganya serta masyarakat umum. Meskipun demikian, kesehatan mental tiga kelompok tersebut di Arab Saudi terpantau normal menurut standar WHO.

Beberapa faktor yang berperan dalam menjaga kesehatan mental masyarakat diantaranya adalah tersedianya layanan konsultasi psikologi secara gratis, baik bagi petugas medis, pasien dan keluarganya serta masyarakat yang mengalami kecemasan akibat corona. Selain itu, nilai-nilai religiusitas yang diinternalisasi dan peran ulama dalam juga menjadi faktor penting, ditambah kebijakan strategis yang diambil pemerintah membuat penanganan Covid-19 menjadi lebih komprehensif. Kerjasama berbagai elemen ini sangat penting mengingat dampak pandemi tidak hanya menyasar kesehatan fisik individu.

\section{SARAN}

Penelitian ini diharapkan bisa dijadikan pembelajaran bagi para stake holders dalam mengambil keputusan terkait kesehatan mental selama masa kritis, terutama pandemi Covid-19. Bagi penelitian selanjutnya, peneliti yang berminat dengan tema ini dapat 

melakukan pengukuran psikologis menggunakan alat ukur yang telah terstandardisasi. Data kuantitatif yang diperoleh akan melengkapi data kualitatif yang disajikan dalam penelitian ini.

\section{DAFTAR PUSTAKA}

Abu-Ras, W., Gheith, A., \& Cournos, F. (2008). The imam's role in mental health promotion: A study at 22 mosques in New York City's Muslim community. Journal of Muslim Mental Health, 3(2), 155176. http://dx.doi.org/10.1080/15564900802487576.

Ali, O. M. (2016). The imam and mental health of muslims: Learning from research with other clergy. Journal of Muslim Mental Health, 10(1), 65-73.

Au, A., Chan, I., Li, P., Chan, J., Chan, Y. H., \& Ng, F. (2004). Correlates of psychological distress in discharged patients recovering from acute respiratory syndrome in Hong Kong. The International Journal of Psychosocial Rehabilitation, 8, 41-51.

Azim, S. S., Dey, D., Aich, A., \& Roy, A. (2020). Fake news in the time of environmental disaster: Preparing framework for COVID-19. SocArXiv. https://doi.org/10.31235/osf.io/wdr5v.

Corrigan, P. W., \& Bink, A. B. (2016). The Stigma of Mental Illness. Chicago: Elsevier.

Creswell, J. W. (2009). Research Design Qualitative, Quantitative, and Mixed Methods Approaches ( $3^{\text {rd }}$ ed.). California: Sage Publications.

Farre, Fasani \& Mueller (2018). "Feeling Useless: The Effect of Unemployment on Mental Health in the Great Recession," Working Papers 774, Queen Mary University of London, School of Economics and Finance.

Frankl, V. E. (1985). Man's Search for Meaning. Boston: Pocket Books.

General Presidency for Scholarly Research and Fatwa (2020) https://twitter.com/aliftasa. Hackney, C. H., \& Sanders, G. S. (2003). Religiosity and mental health: A meta-analysis of recent studies. Journal for the Scientific Study of Religion, 42(1), 43-55.

Johns Hopkins University. COVID-19 Dashboard by the Center for Systems Science and Engineering (CSSE). https://coronavirus.jhu.edu/map.html (diakses pada 4 Mei 2020).

Kang, L., Li, Y., Hu, S., Chen, M., Yang, C., Yang, B. X., Wang, Y., Hu, J., Lai, J., Ma, X., Chen, J., Guan, L., Wang, G., Ma, H., \& Liu, Z. (2020). The mental health of medical workers in Wuhan, China dealing with the 2019 novel coronavirus. Lancet Psychiatry. Published Online February 5. https://doi.org/10.1016/S22150366(20)30047-X.

Kumparan. (2020, Maret 2). Polisi Pasang Police Line di Rumah Warga Depok yang Positif Corona. https://kumparan.com/kumparannews/polisi-pasang-police-line-dirumah-warga-depok-yang-positif-corona-1swnSztIMqm

Lin, C-Y. (2020). Social reaction toward the 2019 novel coronavirus (COVID-19). Social Health and Behavior, 3(1), 1-2.

Livheim, F., Hayes, L., Ghaderi, A., Magnusdottir, T., Hogfeldt, A., Rowse, J., Turner, S., Hayes, S. C., \& Tengstrom, A. (2015). The effectiveness of acceptance and commitment therapy for adolescent mental health: Swedish and Australian pilot outcomes. Journal of Child and Family Studies, 24(3), 1016-1030.

Nicomedes, C. J. C., \& Avila, R. M. A. (2020). An Analysis on the panic of Filipinos during COVID-19 pandemic in the Philippines. 

Pajevic, I., Sinanovic, O., \& Hasanovic, M. (2005). Religiosity and mental health. Psychiatria Danubina, 17(1-2), 84-89.

Person, B., Sy, F., Holton, K., Govert, B., Liang, A., \& National Center for Inectious Diseases/S ARS Community Outreach Team (2004). Fear and stigma: the epidemic within the SARS outbreak. Emerging infectious diseases, 10(2), 358-363. https://doi.org/10.3201/eid1002.030750

Saudi Press Agency. (2020, April 3). Royal Order Approves Exceptions for Unemployment Insurance (SANED) to Mitigate COVID-19 Effects, on Saudis, Working in the Private Sector. https://www.spa.gov.sa/viewfullstory.php?lang=en\&newsid=2069887 (diakses tanggal 6 Mei 2020).

Thakur, V., \& Jain, A. (2020). COVID 2019-suicides: A global psychological pandemic. Brain, behavior, and immunity, S0889-1591(20)30643-7. Advance online publication. https://doi.org/10.1016/j.bbi.2020.04.062.

Thompson, R. W., Arnkoff, D. B., \& Glass, C. R. (2011). Conceptualizing mindfulness and acceptance as components of psychological resilience to trauma. Trauma, Violence, \& Abuse, 12(4), 220-235. https://doi.org/10.1177/1524838011416375.

World Health Organization. (2018). Mental Health: Strengthening Our Response. https://www.who.int/news-room/fact-sheets/detail/mental-health-strengtheningour-response (diakses tanggal 3 Mei 2020).

Wu, K. K., Chan, K.S., \& Ma, M. T. (2005). Posttraumatic stress, anxiety, and depression in survivors of severe acute respiratory syndrome (SARS). J Trauma Stress, 18, 3942.

Xiang, Y. T., Yang, Y., Li, W., Zhang, L., Zhang, Q., Cheung, T., \& Ng, C. H. (2020). Timely mental health care for the 2019 novel coronavirus outbreak is urgently needed. Lancet Psychiatry. Published online Feb 4. https://doi.org/10.1016/S22150366(20)30046-8.

Zhang, J., Wu, W., Zhao, X., Zhang, W., 2020. Recommended psychological crisis intervention response to the 2019 novel coronavirus pneumonia outbreak in China: a model of West China Hospital. Precision Clinical Medicine, 3(1), (3-8).

Zhou, X., Snoswell, C, L., Harding, L. E., Bambling, M., Edirippulige, S., Bai, X., \& Smith, A. C. (2020). The role of telehealth in reducing the mental health burden from COVID-19. Telemedicine and e-Health, 26(4), 377-379. http://doi.org/10.1089/tmj.2020.0068. 